\title{
Hypericum tenuifolium Synonym: Hypericum reductum Atlantic St. John's wort
}

\section{Hypericaceae}

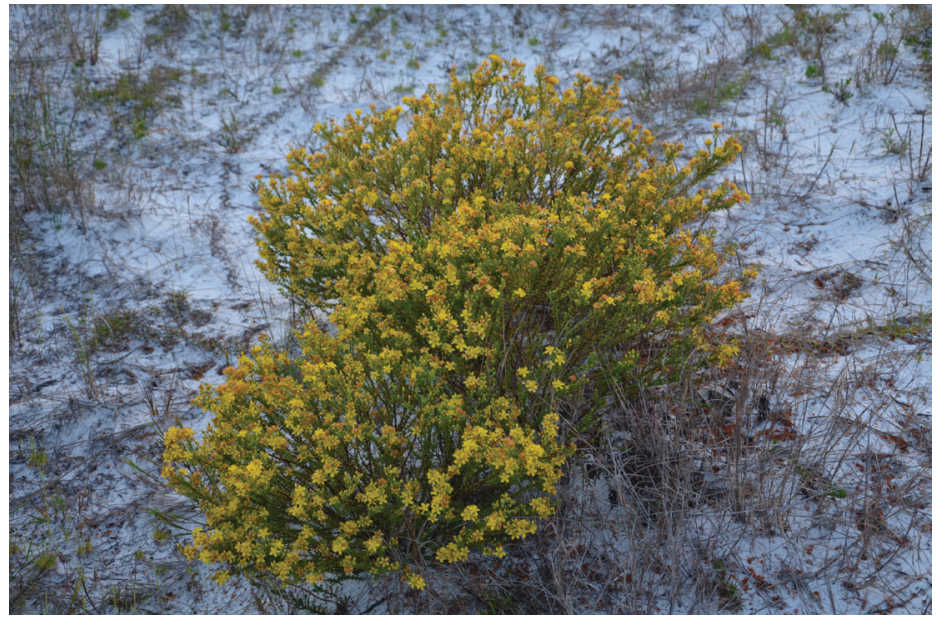

Credit: Gabriel Campbell, UF/IFAS

Atlantic St. John's wort occurs throughout Florida and more broadly west to Alabama and northeast to North Carolina on beach dunes and scrub plant communities frequently associated with wet depression areas. Hypericum is a large genus of plants with 31 species in Florida alone (Wunderlin et al. 2017). This plant is a prolific flower producer that attracts numerous pollinators

\section{General Description}

Atlantic St. John's wort is a semi-woody to herbaceous perennial subshrub with a decumbent growth habit; forming a small rounded shrub to a low mat that rarely reaches above $1.5 \mathrm{ft}$. Leaves are simple, opposite, and needlelike. Stems are often decumbent and matted and are 6-angled in cross-section when young. Flowers have 5 persistent sepals, 5 yellow petals, and bear numerous stamens. They are 0.4 to 01.8 in wide, are axillary and terminal, are solitary or grow in small clusters called cymules or dichasia, and flower from June to September. Fruits are capsules 6 to $10 \mathrm{~mm}$ long and turn brown when ripe.

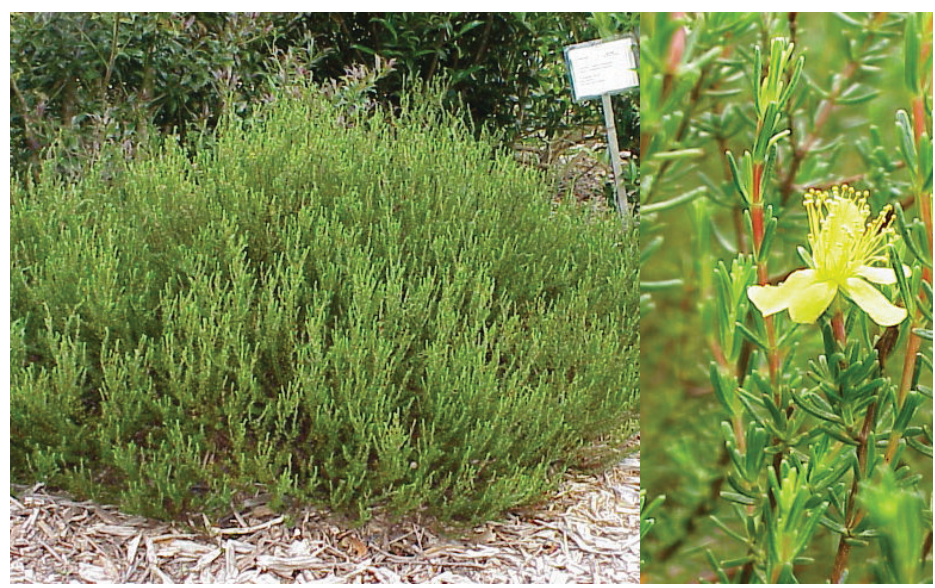

Credit: Mack Thetford, UF/IFAS

\section{Propagation}

Atlantic St. John's wort can be propagated from stem cuttings. The following is adopted from Thetford and Miller (2004). Collect 4 -in terminal stem cuttings during the growing season. Remove leaves of bottom $1 / 2$ in of cutting and quick dip in auxin [NAA (1-Naphthaleneacetic acid) 500 to $1000 \mathrm{ppm}$, or IBA (Indole-3-butyric acid) 1000 to $5000 \mathrm{ppm}$, or Dip 'N Grow] for 1 second (Thetford and Miller 2002). Root cuttings in 72-cell flats with a well-drained substrate under intermittent mist and natural photoperiod. Roots initiate within 2 to 3 weeks. By week 4, rooted cuttings may be removed from mist, and by week 6 , transplants can be moved into larger pots (4-in, 1-qt or 1-gal). Rooted cuttings benefit from fertigation with a complete fertilizer solution providing nitrogen at a rate of $150 \mathrm{ppm} 1$ to 2 times a week before transplanting to larger containers. An additional 4 to 6 weeks of outdoor production with supplemental irrigation is required to develop a full rootball.

No published information on germination requirements of Hypericum tenuifolium is available. Germination

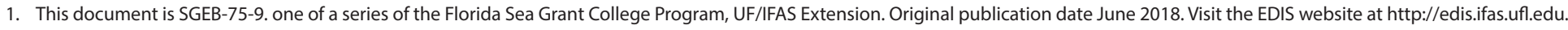

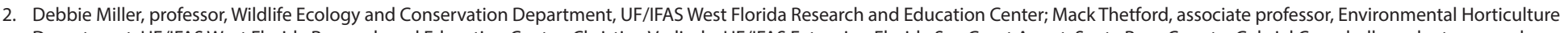

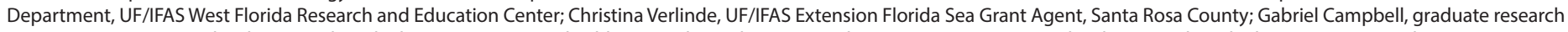

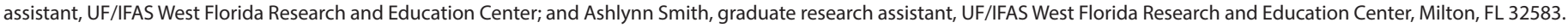


requirements for the related species, $H$. perforatum are variable across populations but need light to germinate with constant $\left(15\right.$ and $\left.25^{\circ} \mathrm{C}\right)$ or fluctuating $\left(25 / 15^{\circ} \mathrm{C}\right)$ day/night temperatures and are non-dormant (Pérez-García et al. 2006). Light has been reported as necessary for germination of other Hypericum sp. with similar optimal germination temperatures, but physiological or physical dormancies have also been reported (Çırak et al. 2007; Çırak 2007.)

\section{Outplanting}

No published information on outplanting information is presently available for Atlantic St. John's wort. The authors have successfully transplanted this species in home landscape situations with minimal supplemental irrigation. In Florida, $H$. tenuifolium is considered a facultative wetland species (occurs in wetlands $67 \%$ to $99 \%$ in the wild) (Wunderlin et al. 2017) and in coastal communities this species is associated with coastal interdunal swales and adjacent low ridges.

\section{Literature Cited}

Campbell, M.H. 1985. "Germination, emergence and seedling growth of Hypericum perforatum L." Weed Research. 25(4):259-266.

Çırak C., K. Kevseroğlu, and A.K. Ayan. 2007. "Break seed dormancy in a Turkish endemic Hypericum species: Hypericum aviculariifolium subsp. depilatum var. depilatum by light and some pre-soaking treatments." Journal of Arid Environments. 68(1):159-164.

Çırak, C. 2007. "Seed germination protocols for Ex situ conservation of some Hypericum species from Turkey." American Journal of Plant Physiology. 2(5):287-294.

Pérez-García, F., M. Huertas, E. Mora, B. Peña, F. Varela, and M.E. González-Benito. 2006. "Hypericum perforatum L. seed germination: interpopulation variation and effect of light, temperature, presowing treatments and seed desiccation." Genetic Resources and Crop Evolution. 53:1187-1198.
Thetford, M., and D.L. Miller. 2002. "Propagation of 4 Florida coastal dune species." Native Plants Journal. 3(2):112-120.

Thetford, M., and D.L. Miller. 2004. Propagation and production of Atlantic St. John's wort. ENH972. Gainesville: University of Florida Institute of Food and Agricultural Sciences. http://edis.ifas. ufl.edu/ep229

Wunderlin, R.P., B.F. Hansen, A.R. Franck, and F.B. Essig. 2017. Atlas of Florida Plants. [S. M. Landry and K. N. Campbell (application development), USF Water Institute.] Institute for Systematic Botany, University of South Florida, Tampa. http://florida. plantatlas.usf.edu/ 